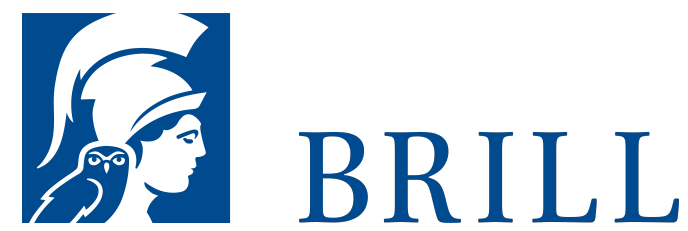

\title{
Wahrheit, Bedeutung und Form
}

Ene Auseinandersetzung mit dem Davidson'schen Programm

Author: M. Hoeltje

Wenige Philosophen des 20. Jahrhunderts haben so einflussreiche und eng verzahnte Beiträge zur Sprachphilosophie, zur Philosophie des Geistes, zur Handlungstheorie und zur Erkenntnistheorie geleistet, wie der Amerikaner Donald Davidson. Eine tragende Säule in Davidsons Theoriegebäude stellt der Begriff einer Bedeutungstheorie für eine Sprache dar. Nur im Rahmen einer solchen Theorie, so Davidson und seine Anhänger, lassen sich Fragen wie die folgenden klären: Welche Folgerungsbeziehungen bestehen zwischen den Sätzen einer Sprache? Haben einige Sätze eine in einer interessanten Weise von ihrer Oberflächenform abweichende logische Form? Welche ontologischen Verpflichtungen geht man ein, wenn man bestimmte Sätze für wahr hält? Bedeutungstheorien sind dieser Ansicht zufolge also ein philosophisches Werkzeug erster Güte. Das vorliegende Buch ist eine kritische Auseinandersetzung mit den Grundlagen des Davidson'schen Ansatzes: Wie lassen sich Bedeutungstheorien formulieren? Welche Rolle spielt eine Wahrheitstheorie hierbei? Stellt die wahrheitstheoretische Semantik tatsächlich die Mittel bereit, um die an eine Bedeutungstheorie geknüpften philosophischen Hoffnungen zu erfüllen?

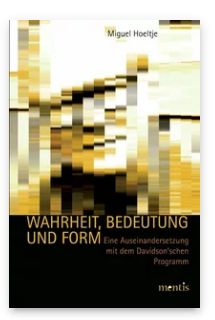

Pages: 296 Seiten

Language:

German

Subjects:

General,

Philosophy

Publisher: Brill | mentis

E-Book (PDF)

Released online:

24 Sep 2012

ISBN: $978-3^{-}$

89785-934-O

List price

USD \$ $\$ 68.00$

Paperback

Publication date:

24 Sep 2012

ISBN: $978-3^{-}$

89785-741-4

List price

USD $\$ 68.00$ 
For more information see brill.com

Order information: Order online at brill.com +44330 333 0049 | customerservices@brill.com Submission information: brill.com/authors

Titles published by Brill | Fink, Brill | mentis or Brill | Schöningh: +49(o)715413279216| brill@brocom.de 